九州大学学術情報リポジトリ

Kyushu University Institutional Repository

\title{
Optimum Conditions for the Assay of Hemolytic Complement Titer of Carp and Seasonal Variation of the Titers
}

Yano, Tomoki

Laboratory of Fisheries Chemistry, Faculty of Agriculture, Kyushu University

Ando, Hiroko

Laboratory of Fisheries Chemistry, Faculty of Agriculture, Kyushu University

Nakao, Miki

Laboratory of Fisheries Chemistry, Faculty of Agriculture, Kyushu University

https://doi.org/10.5109/23797

出版情報: 九州大学大学院農学研究院紀要. 29 (1)，pp.91-101，1984-09. Kyushu University バージョン：

権利関係 : 


\title{
Optimum Conditions for the Assay of Hemolytic Complement Titer of Carp and Seasonal Variation of the Titers
}

\author{
Tomoki Yano. Hiroko Ando and Miki Nakao \\ Laboratory of Fisheries Chemistry, Faculty of \\ Agriculture, Kyushu University 46-04, Fukuoka 812 \\ (Received June 15, 1984)
}

\begin{abstract}
The optimum conditions for the assay of the hemolytic complement titer ( $\mathrm{CH}$, unit $/ \mathrm{ml}$ ) of carp, Cyprinus carpio, was investigated by use of sheep red blood ceils (SRBC) sensitized with carp antiserum. The antiserum was obtained from carp immunized with SRBC stromata for 25 days. The heat inactivation of complement which coexists within the antiserum was performed at $50^{\circ} \mathrm{C}$ for $20 \mathrm{~min}$. The optimum conditions for hemolytic complement reaction were confirmed as follows: reaction temperature, $25^{\circ} \mathrm{C} ; \mathrm{pH}, 7.2$ to 8.5 ; concentrations of $\mathrm{Ca}^{2+}$ and $\mathrm{Mg}^{2+}, 0.1$ to $0.5 \mathrm{mM}$ and 0.5 to $1.0 \mathrm{mM}$, respectively. These results show that the optimum conditions for assaying complement activity of carp are quite similar to those of mammals, and that Mayer's method $\left(37^{\circ} \mathrm{C}, \mathrm{pH} 7.4,0.15 \mathrm{mMCa}^{2+}\right.$ and $\left.0.5 \mathrm{mM} \mathrm{Mg}^{2+}\right)$ is applicable to carp by lowering the reaction temperature from $37^{\circ} \mathrm{C}$ to $30^{\circ} \mathrm{C}$ or below. The complement titers of carps which were obtained from fish farms located in the south of Fukuoka Prefecture, were estimated from September in 1983 till May in 1984. The complement titers gradually decreased as the temperature fell in winter. In spring, the titers began to increase, and again reached high values in May.
\end{abstract}

\section{INTRODUCTION}

The complement system of vertebrate is composed of a series of enzymes which are normally present in fresh serum and play an important role in defending the animal against various infections, i.e., the enzymes react with invading micro-organisms such as bacterium, protozoa and virus and exclude them from body in combination with antibody (classical pathway) or independently (alternative pathway).

The hemolytic complement activity of mammals is usually assayed by Mayer's method (1961). In Mayer's method, one unit of $\mathrm{CH}_{50}$ refers to the amount of complement which needs to hemolyse $50 \%$ of $5 \times 10^{8}$ sheep red blood cells in $7.5 \mathrm{ml}$ of isotonic buffer $(\mathrm{pH} 7.4)$ containing optimum concentrations of $\mathrm{Ca}^{2+}(0.15 \mathrm{mM})$ and $\mathrm{Mg}^{2+}(0.5 \mathrm{mM})$, at $37^{\circ} \mathrm{C}$ for $60 \mathrm{~min}$.

Mammalian antibody does not activate fish complement (Legler and Evans, 1967 a; Ross and Jensen, 1973; Sakai, 1981). Therefore, in order to assay the hemolytic complement activity of fish, one has to prepare red blood cells sensitized with antibody derived from fish. Legler and Evans (1976 a, b) uti- 
lized sheep red blood cells sensitized with natural antibody of fish or turtle antibody for the determination of hemolytic activities of various fish sera. Day et al. (1970) employed rabbit red blood cells sensitized with carp natural antibody. Sakai (1981) used red blood cells of goldfish, rainbow trout, rabbit and sheep sensitized with immune antibody produced by rainbow trout or goldfish. Thus the method for titrating hemolytic complement activity of fish differs among investigators, i. e., they used different kinds of red blood cells and antibodies, and carried out the hemolytic reaction at different temperatures for different reaction times.

The authors investigated the optimum conditions for assaying hemolytic complement titer of carp by use of sheep red blood cells sensitized with the immune antibody produced by carp, and subsequently examined the seasonal change of complement titers of carps which were bred in outdoor crawls of fish farms.

\section{MATERIALS AND METHODS}

\section{Reagents}

The source of reagents used in the present work are as follows: EDTA (ethylenediamine tetraacetic acid, disodium salt) and barbital sodium, Wako Pure Chemical Industries Co., Osaka ; merthiolate (sodium ethylmercurithiosalicylate), Katayama Chemical Industries Co., Osaka; MS-222(tricain methanesulfonate), Sankyo Co., Tokyo; Amberlite IRC-50, Organo Co., Tokyo; sheep blood in Alsever's solution, Japan Bio-Supply Center, Tokyo.

The buffers used in the experiment and their abbreviations are: $\mathrm{GVB}^{2+}$, Veronal-buffered saline, $\mathrm{pH} 7.4$, containing $0.1 \%$ gelatin, $0.15 \mathrm{mM} \mathrm{CaCl}_{2}$ and 0.5 $\mathrm{mM} \mathrm{MgCl}{ }_{2}$;EDTA.GVB, Veronal-buffered saline containing $0.01 \mathrm{M}$ EDTA and $0.1 \%$ gelatin; GGVB, Veronal-buffered saline containing $2.5 \%$ glucose, $0.1 \%$ gelatin; GVB(f), Veronal-buffered saline free from divalent cations, pH 7.4, containing $0.1 \%$ gelatin. GVB(f) was made by passing $200 \mathrm{ml}$ of Veronal-buffered saline containing $0.1 \%$ gelatin through Amberlite IRC-50 (5 ml) and readjusting its $\mathrm{pH}$ to 7.4. Except where noted, $\mathrm{GVB}^{2+}$ was employed in this experiment.

\section{Fish}

Carp, Cyprinus Carpio, weighing 500-700g were purchased from a fish farm near Fukuoka City. Prior to use in the experiment the fishes were maintained in aquaria for more than a month at a water temperature of $24 \pm 1^{\circ} \mathrm{C}$ and on a $14 \mathrm{~L} / 10 \mathrm{D}$ photoregime.

\section{Immunogen}

In order to immunize carp against sheep red blood cells (SRBC), SRBC stroma suspension was prepared as immunogen according to Nishioka (1966).

One hundred $\mathrm{ml}$ of sheep blood in Alsever's solution $(1: 1)$ was centrifuged at $3000 \mathrm{rpm}$ for $10 \mathrm{~min}$, the precipitate was washed twice with $200 \mathrm{ml}$ of 
physiological saline $(0.85 \% \mathrm{NaCl})$ by centrifuging at $3000 \mathrm{rpm}$ for $5 \mathrm{~min}$ and then hemolysed in 1 liter of distilled water containing $0.4 \mathrm{ml}$ of acetic acid. The suspension was allowed to stand overnight at $5{ }^{\circ} \mathrm{C}$, the supernatant was carefully decanted and residual stromata were washed 6 times with $0.01 \mathrm{M}$ acetate buffer ( $\mathrm{pH}$ 5.0) and once with saline, centrifuged at $3000 \mathrm{rpm}$ for 20 min and finally resuspended in $30 \mathrm{ml}$ of saline using a glass-teflon homogenizer.

The content of $\mathrm{N}$ in the stroma suspension was assayed by micro-Kjeldahl method, regulated to $1 \mathrm{mgN} / \mathrm{ml}$ with saline, and stored in a refrigerator after adding $1 / 100$ of $1 \%$ merthiolate.

\section{Immunization of fish}

Every 5 days, 10 carps were anesthetized with MS-222 and injected intraperitoneally with the SRBC stroma suspension $(0.2 \mathrm{ml} / \mathrm{fish})$. At the same time, $0.4 \mathrm{ml}$ of blood was collected from the dorsal aorta of each fish to investigate the time course of antibody production. The injection of stroma suspension was repeated 6 times, whereas the blood-collecting was repeated 10 times (until 20 days after the last injection).

\section{Collection of antiserum and normal serum}

Five days after the last injection, two fish which showed high hemolysin titers were anesthetized and ca. $8 \mathrm{ml}$ of blood was withdrawn from each fish using $2 \mathrm{ml}$ tuberculin syringes with a 24 G-needle. The blood was allowed to stand at $30^{\circ} \mathrm{C}$ for $30 \mathrm{~min}$ and $0^{\circ} \mathrm{C}$ for one hour, the clot was removed by centrifuging at $3000 \mathrm{rpm}$ for $5 \mathrm{~min}$ and the antiserum obtained as supernatant was diluted $1: 2$ with $\mathrm{GVB}^{2+}$, heat inactivated (as described below) and stored at $-35^{\circ} \mathrm{C}$.

Normal sera as a source of complement were obtained in a similar manner uninjected $\mathrm{fish}$ e s, a n d $\mathrm{stored}$ a t $-35^{\circ} \mathrm{C}$ without dilut were stable for at least one month.

\section{He a t i n a c t i v a t i o n o f c o m p l e m e $n$}

The anti-serum obtained from a fish on the 15th day of immunization was diluted $1: 30$ with $\mathrm{GVB}^{2+}, 0.5 \mathrm{ml}$ aliquot was heated at different temperatures $\left(1 \times 10^{9} / \mathrm{ml}\right)$ of SRBC suspe $0.9 \mathrm{ml} \quad$ o $\mathrm{f} \mathrm{GVB}^{2+}$

SRBC.of

$\mathrm{OD}_{541}$

\%lues and 100 


\section{Preparation of sensitized sheep red blood cells (EA)}

Sheep red blood cells were washed with GVB(f) and suspended at a concentration of $1 \times 10^{9} / \mathrm{ml}$ in the same buffer. Antiserum was diluted $1: 100$ to 1 : 200 with EDTA.GVB (the dilution for the optimum sensitization was determined by usual way). Equal volumes of SRBC suspension and of antiserum dilution were mixed and incubated at $30^{\circ} \mathrm{C}$ for $30 \mathrm{~min}$ with occasional shakes. The mixture was cooled and centrifuged at $2000 \mathrm{rpm}$ for $5 \mathrm{~min}$ and the precipitate (EA) was washed twice with GVB(f), and finally suspended in GGVB to give a cell density of $5 \times 10^{8} / \mathrm{ml}$ and stored at $0^{\circ} \mathrm{C}$. Just before use EA was washed and resuspended in $\mathrm{GVB}^{2+}$ or $\mathrm{GVB}(\mathrm{f})$.

\section{Optimum conditions for assaying hemolytic complement titer}

The immune hemolysis reaction was carried out by reducing the total volume of Mayer's method $\left(5.0 \times 10^{8}\right.$ cells $\left./ 7.5 \mathrm{ml}\right)$ to one-fifth $\left(1 \times 10^{8}\right.$ cells $\left./ 1.5 \mathrm{ml}\right)$

1) reaction temperature

The effect of temperature on hemolytic reaction was investigated as follows : the mixture of $0.2 \mathrm{ml}$ of EA $\left(5 \times 10^{8} / \mathrm{ml}\right), 0.8 \mathrm{ml}$ of $\mathrm{GVB}^{2+}$ and $0.5 \mathrm{ml}$ of complement diluted with $\mathrm{GVB}^{2+}$ to give 70 to $80 \%$ hemolysis $(1: 20$ to $1: 30$ ) was incubated at different temperatures ranging from $10^{\prime}$ to $37^{\circ} \mathrm{C}$ for $60 \mathrm{~min}$, followed by cooling and centrifuging at 3000 r p m fo

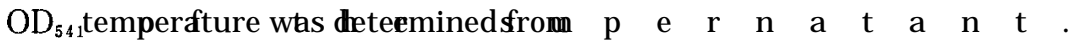

2) $\mathrm{pH}$

The $\mathrm{pH}$ of $\mathrm{GVB}^{2+}$ was readjusted to various $\mathrm{pH}$ 's ranging from 5.8 to 9.0 $\begin{array}{llllllllllllllll}\mathrm{b} & \mathrm{y} & \mathrm{a} & \mathrm{d} & \mathrm{d} & \mathrm{i} & \mathrm{n} & \mathrm{g} & 1 & \mathrm{~N} & \mathrm{HCl} & \mathrm{o} & \mathrm{r} & 1 & \mathrm{~N} & \mathrm{NaOH}, \text { and hemolytic react }\end{array}$ $\mathrm{pH}$. The reaction mixtures were incubated at $30^{\circ} \mathrm{C}$ for $60 \mathrm{~min}$ and centrifuged, and hemolysis rate at each $\mathrm{pH}$ was calculated from $\mathrm{OD}_{541}$ of the supernatant.

3) concentrations of $\mathrm{Ca}^{2+}$ and $\mathrm{Mg}^{2+}$

In order to remove as much $\mathrm{Ca}^{2+}$ and $\mathrm{Mg}^{2+}$ as possible, $0.5 \mathrm{ml}$ of complement was passed through an Amberlite IRC-50 (3 ml), then $2.8 \mathrm{ml}$ of GVB(f) was added to the column, the first eluate $(0.3 \mathrm{ml})$ being discarded and the next eluate $(2.5 \mathrm{ml})$ being collected. This eluate was further diluted $1: 3$ with GVB (f).

Aliquot $(0.5 \mathrm{ml})$ of the above cation free eluate (complement) and $10 \mu \mathrm{l}$ aliquots of $\mathrm{CaCl}_{2}$ solution and $\mathrm{MgCl}_{2}$ solution were added to $0.2 \mathrm{ml}$ of $\mathrm{EA}$, and then the total volume was controlled to $1.5 \mathrm{ml}$ with $\mathrm{GVB}(\mathrm{f})$. The mixtures were incubated at $30^{\circ} \mathrm{C}$ for $60 \mathrm{~min}$. After cooling and centrifuging, the hemolysis rate was calculated from $\mathrm{OD}_{541}$ in the supernatant. In refernce to Mayer's method, the optimum concentration of $\mathrm{Ca}^{2+}$ was examined in the presence of $0.5 \mathrm{mM} \mathrm{Mg}^{2+}$, whereas that of $\mathrm{Mg}^{2+}$ was investigated in the presence of 0.15 $\mathrm{mMCa}^{2+}$. The concentrations of $\mathrm{Ca}^{2+}$ and $\mathrm{Mg}^{2+}$ were measured by use of atomic absorption spectophotometer (Nippon Jarrell-Ash Co., AA-500).

\section{Assay of hemolytic complement titer $\left(\mathrm{CH}_{50}\right)$}

Diluted complement $\left(1: 20\right.$ to $1: 40$ with $\left.\mathrm{GVB}^{2+} ; 0.4,0.6,0.8 \mathrm{ml}\right)$ was added to $0.2 \mathrm{ml}$ of EA $\left(5 \times 10^{8} / \mathrm{ml}\right)$ and the total volume was adjusted to $1.5 \mathrm{ml}$ with $\mathrm{GVB}^{2+}$. The mixture was incubated at $30^{\circ} \mathrm{C}$ for $60 \mathrm{~min}$, and hemolysis rate, 
$y$, was calculated from $\mathrm{OD}_{541}$ of the supernatant.

The values of $\mathrm{y} /(1-\mathrm{y})$ were plotted on a log-log scaled graph paper (X. axis was $\mathrm{y} /(1-\mathrm{y})$ and $\mathrm{Y}$-axis was $\mathrm{ml}$ of diluted complement), the volume $(\mathrm{ml})$ which gives 50 \% hemolysis $[y /(1-y)=1]$ was read on the graph and complement titer $\left(\mathrm{CH}_{50}\right.$ unit/ $\left.\mathrm{ml}\right)$ was calculated as follows:

$$
\text { complement titer }\left(\mathrm{CH}_{50} \text { unit/ } \mathrm{ml}\right) \stackrel{\text { dilution of complement }}{=} \times \frac{1}{\mathrm{ml}^{-1} \text { of }-50 \% \text { hemolysis }} \times \frac{1}{5}
$$

\section{Assay of hemolysin titer}

Antiserum (carp anti-SRBC hemolysin) was diluted with $\mathrm{GVB}^{2+}$ by a twofold dilution method ( $1: 50,1: 100,1: 200 \ldots)$ at a volume of $0.5 \mathrm{ml}$ in small test tubes, then $0.1 \mathrm{ml}$ of SRBC suspension $\left(1 \times 10^{9} / \mathrm{ml}\right), 0.4 \mathrm{ml}$ of $\mathrm{GVB}^{2+}$ and $0.5 \mathrm{ml}$ of complement diluted 1:20 to 1: 40 were successively added to the tubes. The mixture was incubated at $30^{\circ} \mathrm{C}$ for $60 \mathrm{~min}$, centrifuged at $3000 \mathrm{rpm}$ for $5 \mathrm{~min}$, and hemolysis rate $(y)$ was calculated from $O_{541}$ in the supernatant. The value of $y$ was plotted on a semi-logarithmic graph paper ( $Y$-axis was $y$ and logarithmic $X$-axis was the dilution of hemolysin). Hemolysin titer, the dilution giving $50 \%$ hemolysis $(y=0.5)$, was read on the graph.

\section{RESULTS}

\section{Antibody production of carp}

Ten carps were inoculated with $0.2 \mathrm{ml}$ of SRBC stroma suspension 6 times at 5-day intervals and the time course of their antibody production was followed by assaying hemolysin titers (Fig. 1). The hemolysin titer of each fish began to rise on the 15th day and reached to maximum by the 25th to 35th day of immunization. The injection of immunogen was stopped on the 25th day, but the hemolysin titers of several fishes continued to rise until the 30th day and then gradually decreased till the end of experiment. As shown in Fig. 1, there was little difference in days for the hemolysin titers of each fish to reach to maximum, though the variation of their titers among indivisual fishes were very large.

\section{Heat inactivation of complement}

In order to investigate the condition for the heat inactivation of complement which coexists within serum, carp antiserum was heated at various temperatures for $20 \mathrm{~min}$, and the remaining hemolytic activity was assayed by adding defined number of SRBC. As Fig. 2 shows, the inactivation of carp antiserum was successfully accomplished by heating at $50^{\circ} \mathrm{C}$ for $20 \mathrm{~min}$. Heat inactivated antiserum was stable for at least 3 months at $-35^{\circ} \mathrm{C}$.

\section{Optimum conditions for assaying hemolytic complement titer $\left(\mathrm{CH}_{50}\right)$}

The total reaction volume of Mayer's method was reduced to one-fifth, and the hemolytic activity of carp complement was measured at various temperatures ranging from $10^{\prime \prime}$ to $37^{\circ} \mathrm{C}$ for $60 \mathrm{~min}$. As shown in Fig. 3, the hemo- 


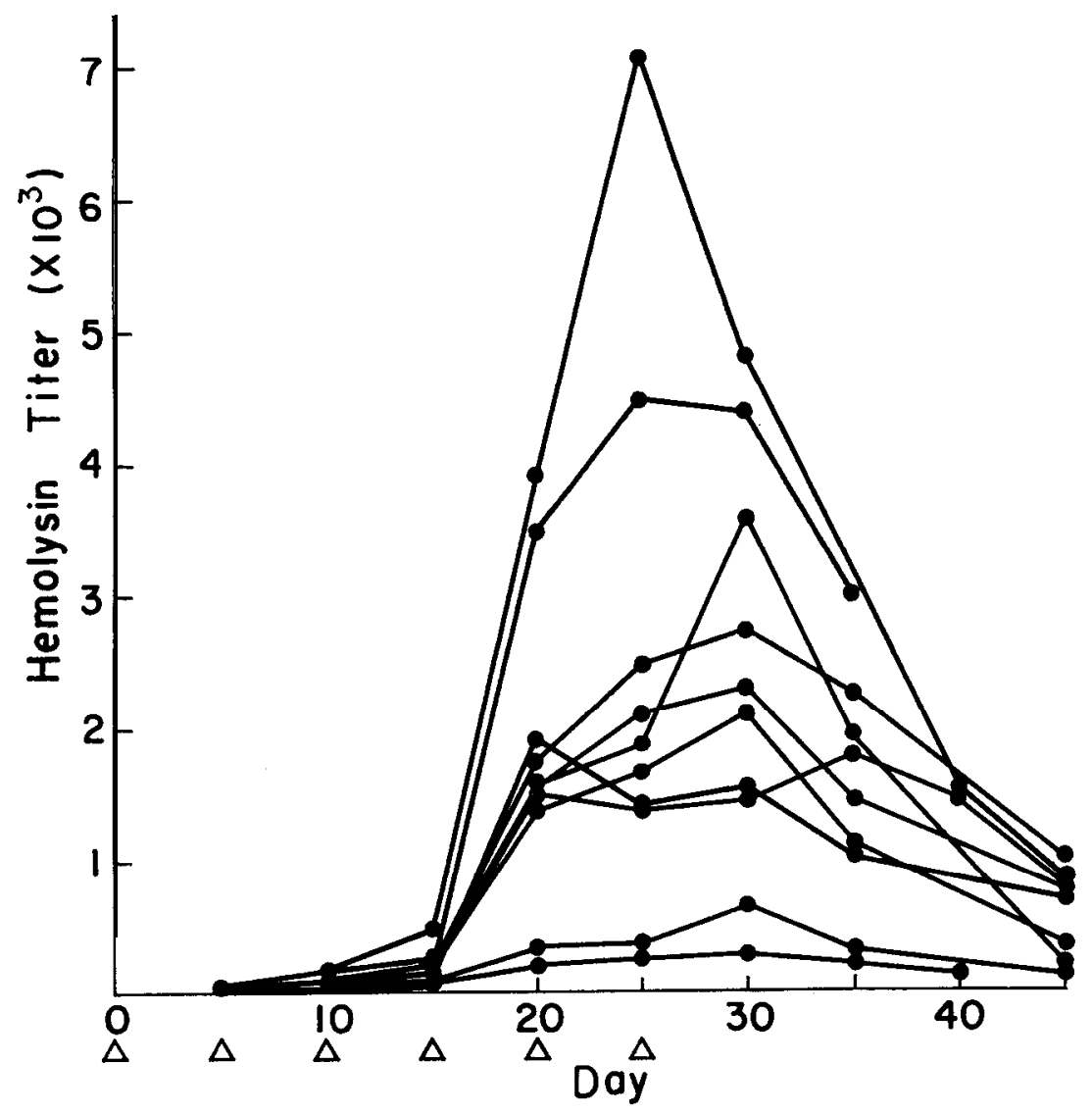

Fig. 1. Antibody productions of ten carps injected with SRBC stroma suspension $(1 \mathrm{mgN} / \mathrm{ml})$. The hemolysin titer of each fish was assayed at 5day intervals until the 45th day. Triangles indicate the days of injection of SRBC stroma suspension $(0.2 \mathrm{ml} /$ fish $)$.

lysis rate was maximum at $25^{\circ} \mathrm{C}$ and maintained high levels of activity in the range of $20^{\prime \prime}$ to $30^{\circ} \mathrm{C}$, while at $37^{\circ} \mathrm{C}$, SRBC were scarcely hemolyzed in contrast to mammals.

As shown in Fig. 4, the hemolytic reaction was also performed at different pH's ranging from 5.8 to 9.0. Consequently, the highest hemolysis rate was observed at pH's from 7.2 to 8.5 , but hemolysis rate dropped rapidly at $\mathrm{pH}$ 's below 7.2.

Fig. 5 a shows the change of hemolysis rate when the $\mathrm{Ca}^{2+}$ concentration was altered from $10^{-6}$ to $10^{-2} \mathrm{M}$ in the presence of $0.5 \mathrm{mM} \mathrm{Mg}^{2+}$, whereas Fig. $5 \mathrm{~b}$ shows the change of hemolysis rate when $\mathrm{Mg}^{2+}$ concentration was altered from $10^{-6}$ to $10^{-2} \mathrm{M}$ in the presence of $0.15 \mathrm{mMCa}^{2+}$. The figures show that hemolytic reaction scarcely proceed at $\mathrm{Ca}^{2+}$ or $\mathrm{Mg}^{2+}$ concentration lower than 


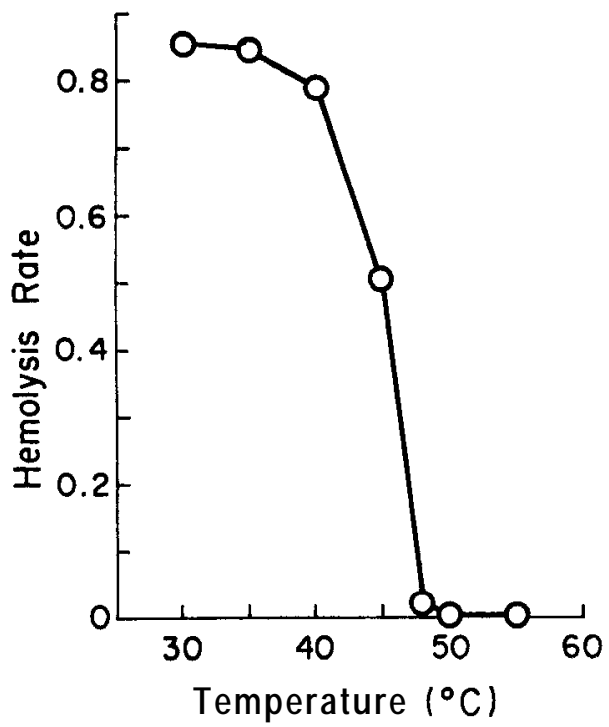

Fig. 2. Heat inactivation of carp complement. Anti-SRBC carp serum was heated at $30^{\prime \prime}$ to $50^{\circ} \mathrm{C}$ for $20 \mathrm{~min}$, and residual hemolytic activity was assayed by adding the defined number of SRBC at $30^{\circ} \mathrm{C}$ for $60 \mathrm{~min}$.

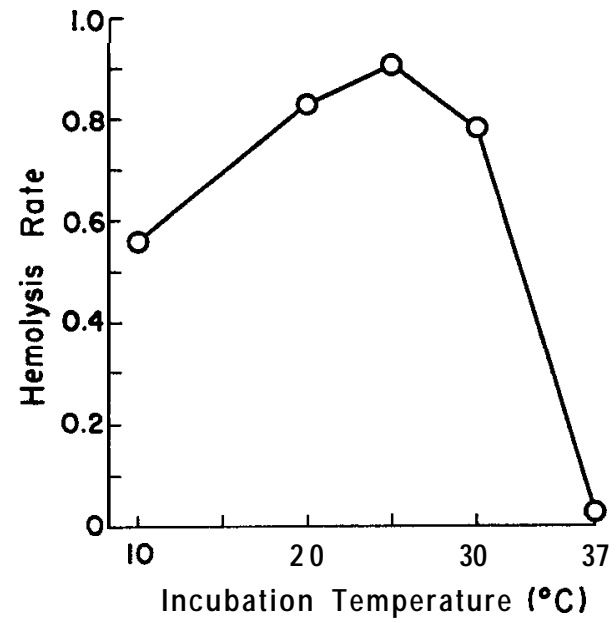

Fig. 3. Effect of incubation temperature on the hemolytic activity of carp complement. The reaction was performed at $\mathrm{pH} 7.4$ for $60 \mathrm{~min}$.

$10^{-6} \mathrm{M}$. This indicates that both cations are indispensable for complement activity. The optimum concentrations of $\mathrm{Ca}^{2+}$ and $\mathrm{Mg}^{2+}$ were $1 \times 10^{-4}$ to $5 \times 10^{-4}$ $\mathrm{M}$ and $5 \times 10^{-4}$ to $1 \times 10^{-3} \mathrm{M}$, respectively.

In conclusion, Mayer's method is applicable to the titration of fish com- 


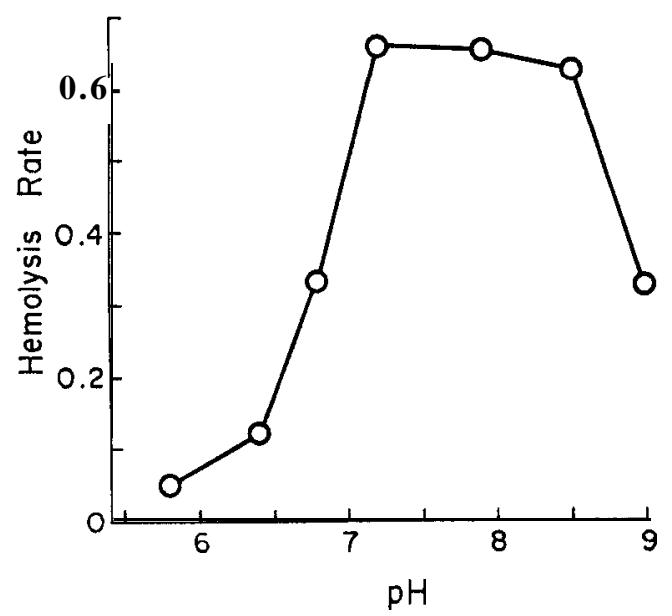

Fig. 4. Effect of $\mathrm{pH}$ on the hemolytic activity of carp complement. The reaction was performed at $30^{\circ} \mathrm{C}$ for $60 \mathrm{~min}$.
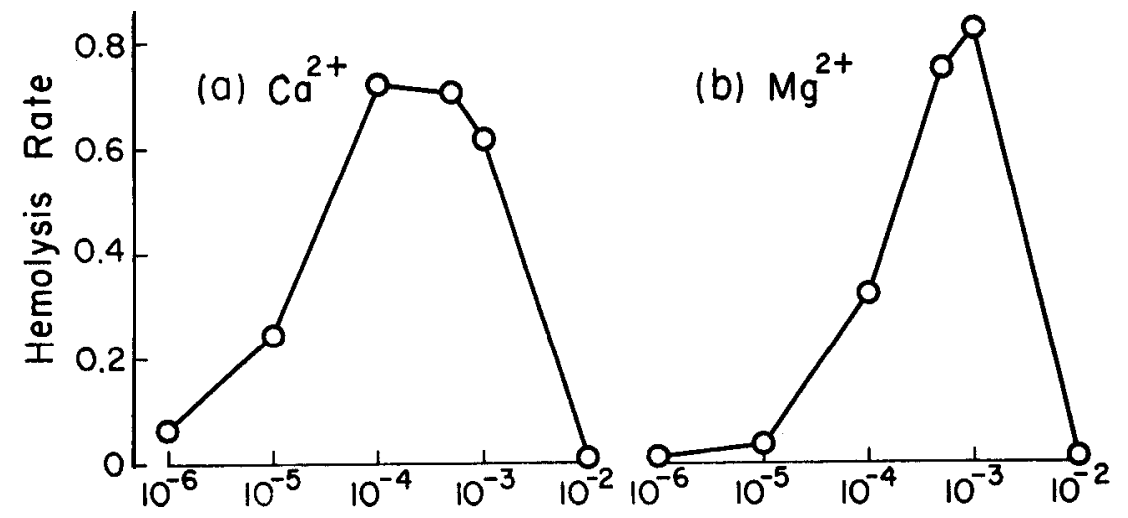

Final Concentrations of $\mathrm{Ca}^{2+}$ and $\mathrm{Mg}^{2+}(\mathrm{M})$

Pig. 5. Effects of concentrations of $\mathrm{Ca}^{2+}$ and $\mathrm{Mg}^{2+}$ on the hemolytic activity of carp complement. The reaction was performed at $30^{\circ} \mathrm{C}$ for $60 \mathrm{~min}$.

(a) Concentration of $\mathrm{Ca}^{2+}$ was varied in the presence of $5 \times 10^{-4} \mathrm{M} \mathrm{MgCl}_{2}$.

(b) Concentration of $\mathrm{Mg}^{2+}$ was varied in the presence of $1.5 \times 10^{-4} \mathrm{M} \mathrm{CaCl}_{2}$.

plement activity by modifying its reaction temperature. As mentioned above, the optimum reaction temperature of carp complement was $25^{\circ} \mathrm{C}$. However, the authors adopted $30^{\circ} \mathrm{C}$ instead of $25^{\circ} \mathrm{C}$ since the room temperature of our laboratory exceeds $25^{\circ} \mathrm{C}$ during summer.

\section{Stability of complement.}

It is generally said that fish complement is more labile than those of mammals. Therefore, an experiment was performed to recognize the stability 


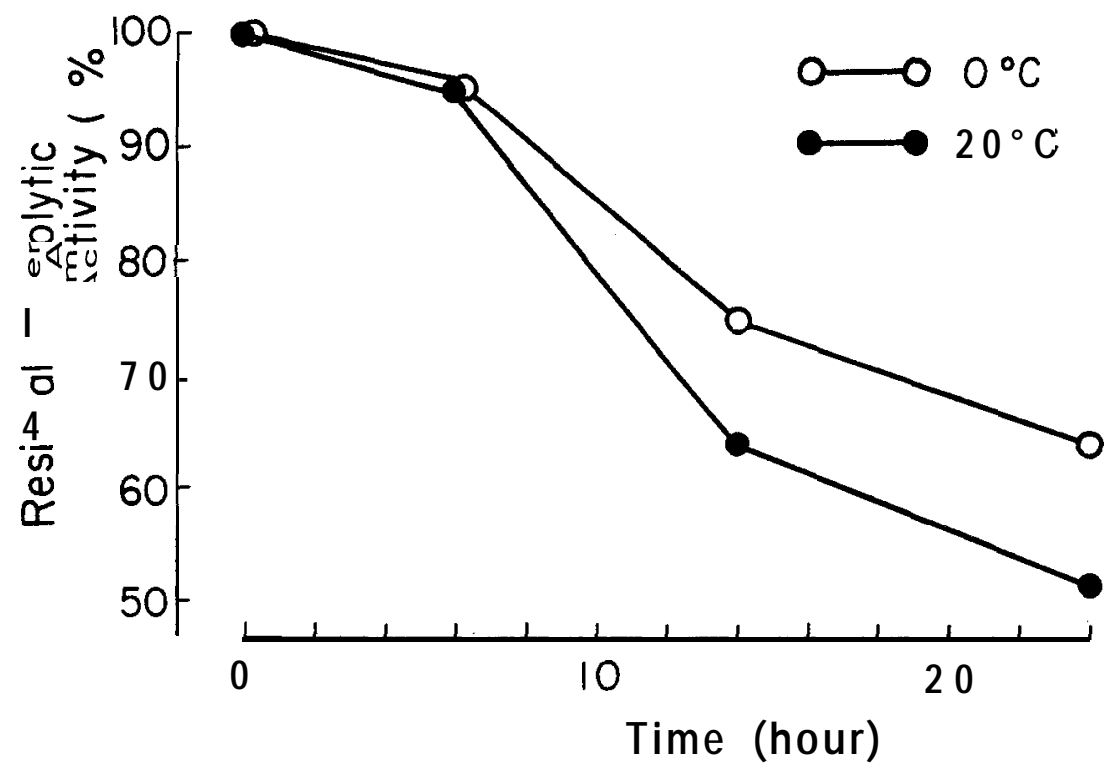

Fig. 6. Stability of carp complement which was allowed to stand at $0^{\circ} \mathrm{C}$ or $20^{\circ} \mathrm{C}$ for 24 hours. Residual hemolytic activity was expressed as percentage of the intial one.

of carp serum. The samples frozen at $-35^{\circ} \mathrm{C}$ were thawed at room temperature and then allowed to stand at $0^{\circ} \mathrm{C}$ or $20^{\circ} \mathrm{C}$ for 24 hours. Fig. 6 shows that at both temperatures the lowering of complement activities were less than 5 $\%$ within 6 hours, and that rapid reduction of activities occurred thereafter, i.e., the samples kept at $0^{\circ} \mathrm{C}$ showed 36 decrease in activity at the end of experiment, while those kept at $20^{\circ} \mathrm{C}$ showed $48 \%$ decrease.

\section{Seasonal variation of complement titers of carp}

Carps, weighing 500-700 g, were captured several times at fish farms located in the south of Fukuoka Prefecture from early in September in 1983 till late in May in 1984. The blood was collected by bloodletting from the caudal peduncles and the hemolytic complement titer $\left(\mathrm{CH}_{50}\right)$ of the serum was assayed according to the method described above. As seen in Fig. 7, the complement titers gradually decreased as the temperature fell in winter. However, the complement titers began to increase in early spring and reached high values averaging $22.4 \mathrm{CH}_{50}$ units/ml in May.

\section{DISCUSSION}

In order to determine the cotnplement activity of carp, we prepared sheep red blood cells (SRBC) sensitized with carp antibody, because fish complements are incompatible with mammalian antibodies. The authors employed SRBC stromata instead of SRBC for immunization of carp, since the former has the 


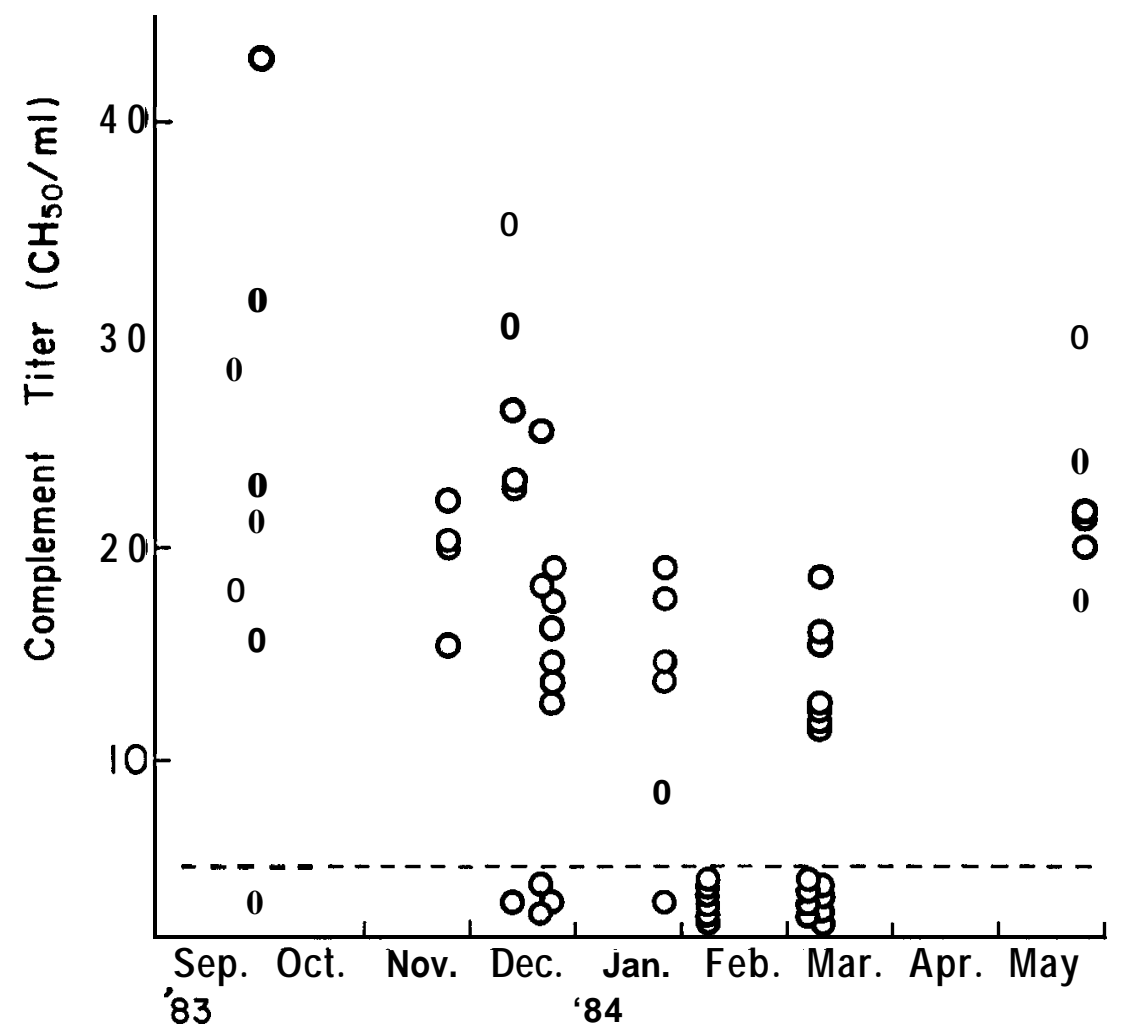

Fig. 7. Seasonal variation of complement titers of carps which were bred in outdoor crawls of fish farms.

advantages of giving low agglutination titer and of yielding antibody suitable for hemolytic reaction. In the preliminary studies, boiled stroma suspension (Nishioka, 1966) was used as immunogen, but it failed to elevate antibody titer. Therefore, in this experiment stroma suspension was injected without boiling.

The carp injected with SRBC stroma suspension successively 6 times at 5 day intervals produced a high levels of hemolysin titers (Fig. 1). On the contrary, the primary immune response of carp was not so high as was expected, i.e., the hemolysin titers of carp injected with the same immunogen only once were lower than 200 throughout the experiment.

It is also demonstrated in this experiment that Mayer's method which was devised for the titration of mammalian complement was applicable to carp complement by modifying the reaction temperature from $37^{\circ} \mathrm{C}$ to $30^{\circ} \mathrm{C}$ or below. The optimum hemolytic reaction temperatures reported by several investigators are different among fishes e.g., $28^{\circ} \mathrm{C}$ for goldfish and elasmobranchs (Legler and Evans, $1967 \mathrm{a}, \mathrm{b}) ; 30^{\circ} \mathrm{C}$ for carp, nurse shark, etc. (Day et al., $1970) ; 30^{\circ} \mathrm{C}$ for rainbow trout and goldfish (Sakai, 1981) ; $25^{\circ} \mathrm{C}$ for rainbow 
trout (Nonaka et al., 1981). The carp complement showed a high hemolytic activity over a wide range of $20^{\prime \prime}$ to $30^{\circ} \mathrm{C}$ in this experiment. This property may be advantageous to poikilothermic animals such as fish.

The hemolytic complement titers of the sera which were allowed to stand at $0^{\circ} \mathrm{C}$ and $20^{\circ} \mathrm{C}$ for 24 hours decreased by $36 \%$ and $48 \%$, respectively. This result was in a marked contrast to that obtained from guinea pig serum which showed $8 \%$ decrease at $0^{\circ} \mathrm{C}$ and $19 \%$ decrease at $20^{\circ} \mathrm{C}$ in 24 hours (Yano et al., unpublished). Therefore carp serum should be kept at $0^{\circ} \mathrm{C}$ after thawing and has to be used as soon as possible (within 6 hours).

The hemolytic complement titers of carp were very low in winter. This may be due to the reduction of fish's taking foods because the fishes fed in aquaria $\left(2411^{\circ} \mathrm{C}\right)$ in this season showed appreciablly high levels of complement titers.

\section{REFERENCES}

Day, N. K. B., H. Gewurz, R. Johannsen, J. Finstad and R. A. Good 1970 Complement and complement-like activity in lower vertebrates and invertebrates. J. Exp. Med., $132: 941-950$

Legler, D. W. and E. E. Evans 1967 a Comparative immunology: hemolytic complement in elasmobranchs. Proc.Soc. Exp. Biol. Med., 124: 30-34

Legler, D. W. and E. E. Evans 1967 b Comparative immunology: serum complement of freshwater fishes. Trans. Am. Fish. Soc., 96: 237-242

Mayer, M. M. 1961 In "Experimental Immunochemistry," 2nd ed. by E. A. Kabat and M. M. Mayer, Thomas Springfield, Ill., pp. 149-153

Nishioka, K. 1966 Methods for preparing anti-sheep erythrocyte antibody. Protein, Nucleic acid and Enzyme, 11: 1485-1486 (in Japanese)

Nonaka, M., N. Yamaguchi, S. Natsuume-Sakai and M. 'Takahashi 1981 The complement system of rainbow trout (Salmo gairdneri) I. Identification of the serum lytic system homologous to mammalian complement. J. Zmmunol., 126: 1489-1494

Ross, G. D. and J. A. Jensen 1973 The first component of the complement system of the nurse shark (Ginglymostoma cirratum) I. Hemolytic characteristics of partially purified Cln. J. Immunol., 110: 175-182

Sakai, D. K. 1981 Spontaneous and antibody-dependent hemolysis activities of fish sera and inapplicability of mammalian complements to the immune hemolysis reaction of fishes. Bull. Japan. Soc. Sci. Fish., 47: 979-991 